\title{
LESTES ALBOFASCIATA : A NEW SPECIES OF ODONATA FROM BURU ISLAND
}

\author{
By Lt.-Col. F. C. Fraser, I.M.S. Retd., F.R.E.S.
}

IN the course of writing a monograph on the Legion Lestes Selys, I made a critical examination of my large collection of species from the Oriental region, and found among them a specimen labelled "Buru, Forster", which is undoubtedly a species new to science. This specimen was passed on to Dr. Laidlaw, I believe, some years ago, and I had formerly misread the label as "Borneo".

This new species belongs to the large complex praemorsa which, I find, falls naturally into two sections according to whether the pectus of thorax and, more especially, the ventro-lateral border of the metepimeron is spotted with black or not. The new species belongs to the first category which includes not only species from the Orient, but also a small Ethiopian section, viz. L. simulatrix McLachlan, L. tridens McLachlan, L. simulans Martin and L. pruinescens Martin. The latter is, I think, merely the very adult form of L. simulatrix from Madagascar, or its continental form. I have named the new species $L$. albofasciata from the unique pale bluish-white fascia which traverses each side of the thorax, and its description follows :-

\section{Lestes albofasciata $\mathrm{sp} . \mathrm{n}$.}

Male. Abdomen $36 \mathrm{~mm}$. Hind-wing $23 \mathrm{~mm}$. (ㅇ unknown). Head: labium pale yellow, labrum, bases of mandibles and genae pale turquoise blue; ante- and post-clypeus black, the latter with a submedial spot of blue on each side; rest of head dull black, including behind the eyes, save for a small quadrate spot of yellow bordering the outer side of each lateral ocellus. Prothorax pale bluish with a broad middorsal black stripe, the median suture anteriorly yellow just behind the anterior lobe. Laterally a narrow black stripe broadening and forking deeply anteriorly. Thorax pale bluish-white marked very broadly with sharply defined coal-black stripes and areas, that on the dorsum being dark blue metallic. Mid-dorsum with the conventional praemorsa crenulate stripes which, however, are confluent in the middle line and broader than in any other known species, extending in places almost to the humeral suture and the indentations much flattened out. Laterally a small black spot on the superior end of humeral suture, another adjacent to the lower end of this suture, a small spot on the spiracle and the whole of the lower sides and beneath. The upper anterior limit of this black fascia is very clearly defined and begins just at the level of the incomplete suture; a small spot of the ground-colour and some irregular ungulate indentations posteriorly are the only relief to this extensive black area (fig. I). Legs very long and slim, yellow with narrow black stripes on the outer and extensor surfaces of femora, broad and confluent apically on the anterior pair. Wings hyaline : 13 and 15 postnodals in fore-wings, 14 and 15 in the hind pair. Pterostigma black, rather short, scarcely more than twice as long as broad, covering 2 cells, distal and proximal sides equally oblique. Abdomen black on dorsum, blue laterally and beneath, the black as a quadrate spot on dorsum of segment 1, not quite extending to apical border of segment, a broad thistle-head-shaped stripe on dorsum of segment 2, not quite extending to base of segment where a broadish blue annule thus separates the two first segments; segments 3 to 6 with narrow black apical rings and black dorsal bands which taper to a PROC. R. ENT. SOC. LOND. (B) 12. PTS. 7-8. (AUG. 1943.) 
point basally and broaden subapically to form broad subapical annules narrowly connected to the apical ones; segment 7 with a basal blue ring covering about one-fourth the

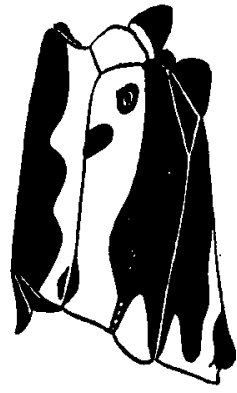

a

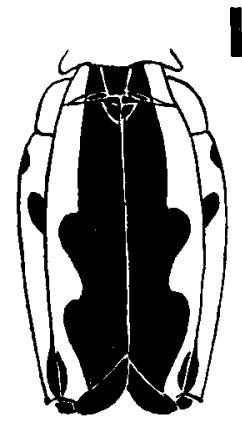

b

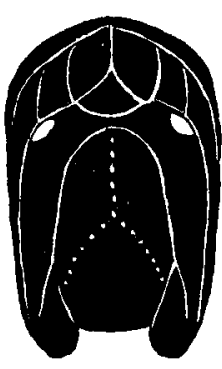

c

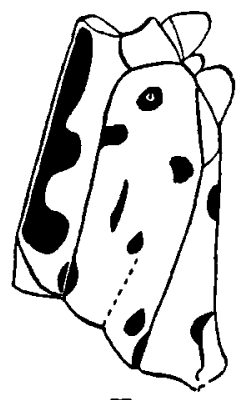

d

FIG. 1.-Lestes albofasciata sp. n. a. Right lateral view of thorax. b. Dorsal view of thorax. c. Pectus. d. Lestes praemorsa Selys, right lateral view of thorax to contrast with a.

segment; segments 8 to 10 entirely black. Anal appendages: superiors entirely pale creamy yellow, shaped very similar to those of praemorsa typica, about half as long again as segment 10, the inner plate narrower than in praemorsa and rather abruptly expanded

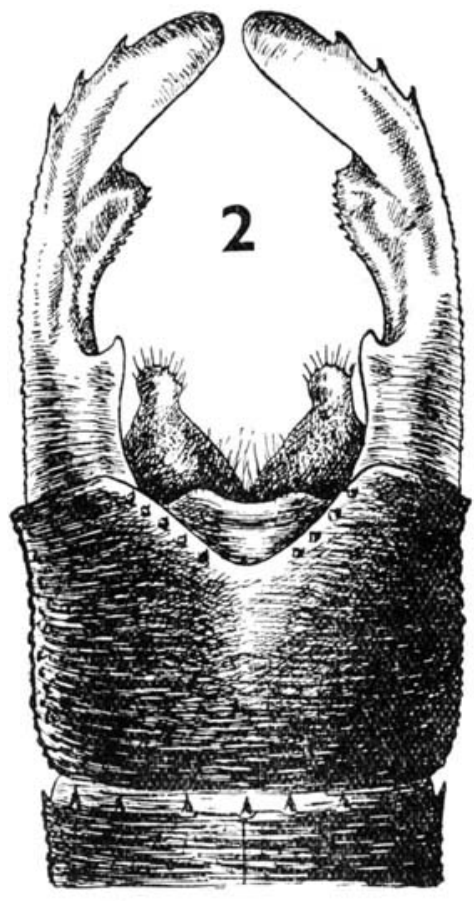

FIG. 2.-Lestes albofasciata sp. n. Dorsal view of tenth segment and anal appendages of male. 
at the apical end which is very finely dentate. Apices evenly incurved and with a few bordering spines. Inferiors brownish, pale yellow at base and extreme apex, broad at base, mammilated at apex, not extending as far as the inner basal spine of superiors (fig. 2).

Habitat: Buru. The type will be deposited in the British Museum. The late Dr. Ris mentions specimens of $L$. praemorsa from Buru (1929, Treubia, 7 (Suppl.) : 141), but states that they do not differ from those from Sumatra. He mentions, however, that the superior anal appendages are entirely pale and that the pterostigma is shorter and blacker than usual, thus these may represent the sub-adult state of this new species. Owing to the extensive black fascia, it is impossible to say whether the usual ventro-lateral black spots on the lower border of metepimeron common to the first section of praemorsa are present or not.

\title{
MYRMECOLOGICAL GLEANINGS
}

\author{
By Horace Donisthorpe, F.Z.S., F.R.E.S.
}

IN the course of work during the last twelve months the following myrmecological matters, to which attention should be called, have come to notice.

\section{Ponerinae.}

\section{Formicidae.}

1. Ponera tortuolosa Smith, 1858, Cat. Hym. Brit. Mus. 6:99, ఫ, and Ponera tortuolosa Smith, 1863, Journ. Proc. Linn. Soc. Lond. Zool. 7 : 18, 우. The first species, from Brazil, belongs to the subgenus Gnamptogenys Roger of Ectatomma Smith, and the second, from Ceram, is a subspecies of Diacamma rugosum Le Guil. Nevertheless as they were both originally described as Ponera tortuolosa, the latter insect requires a new name, for which I propose D. rugosa Le Guil, subsp. smithi nom. n.

2. Rhytidoponera (Rhytidoponera) hilli Crawley, 1915, Ann. Mag. nat. Hist. $15: 131, \nvdash$, and Rhytidoponera (Chalcoponera) hilli Clark, 1941, Mem. Nat. Hist. Mus. Melbourne 12: 85, $\not$, both from Australia. For the latter species I propose the name R. (C.) clarki nom. n.

\section{Myrmicinae.}

3. Acromyrmex (Acromyrmex) nobilis Santschi. Santschi, in 1939, described this species twice, though not entirely in the same words, on four workers taken in Brazil. The descriptions may be found in "Etudes et Descriptions de Fourmis néotropiques," 1939, Rev. Ent. Rio de J. $10: 317$; and "Résultats

PROC. R. ENT. SOC. LOND. (в) 12. PTS. 7-8. (AUG. 1943.) 